\title{
Ginger Processing in India (Zingiber officinale): A Review
}

\author{
Bijaya B. Bag* \\ Department of Agricultural Engineering, Centurion University of Technology and \\ Management, Odisha- 761211, India \\ *Corresponding author
}

\begin{tabular}{|l|l|}
\hline \multicolumn{2}{c|}{ A B S T R A C T } \\
\cline { 2 - 2 } \begin{tabular}{l}
\hline Key w ords \\
$\begin{array}{l}\text { Ginger (Singiber } \\
\text { officinale Roscoe) }\end{array}$
\end{tabular} & $\begin{array}{l}\text { Ginger (Zingiber officinale Roscoe) is a spice of great commercial importance belongs to } \\
\text { the Zingiberacea family. The leading states producing ginger in India are Orissa, Kerala, } \\
\text { Karnataka, Sikkim, West Bengal, Arunachal Pradesh, and Madhya Pradesh. Kerala, is } \\
\text { being partly responsible for 33 per cent of the total production in India. Different varieties } \\
\text { of ginger, its nutritional composition and production status have discussed. This also } \\
\text { highlighted uses of Ginger, processing methods like drying, splitting/slicing, mechanical } \\
\text { expression, and post-harvest operations and processed products like fresh, dried, } \\
\text { preserved, pickled, crystallized or(candied) and powdered or ground, essential oils and } \\
\text { oleoresin processing and extraction methods. Various government schemes and export } \\
\text { potential of ginger with respect to Indian scenario has also discussed. }\end{array}$ \\
\hline $\begin{array}{l}\text { Accepted: } \\
\text { Available Online: } \\
10 \text { April 2018 }\end{array}$ &
\end{tabular}

\section{Introduction}

Ginger is an ancient medicinal plant belonging to Zingiberaceae family which is officially known as Zingiber officinale Rosc and it is indigenous to south-eastern Asia (Purseglove et al., 1981). It is one of the earliest known treasured spices esteemed for its pungency and aroma, viewed as a healing gift from God by Indian Ayurvedic systems. Since a very long time ginger is known for its medicinal value as a digestive aid, spiritual beverage, aphrodisiac, antiemetic, anticancer, anti-platelet, antimicrobial, anti-parasitic, anti-oxidant, antiinflammatory, analgesic, hepato-protective, and immune stimulating properties (Malhotra and Singh, 2003). India is the largest producer and consumer of ginger contributing about $31 \%$ of total global production followed by
China, Nepal, Indonesia, Nigeria, and Thailand. In the countries such as Canada, U.K, U.S.A. ginger is used in soft drink manufacturing industry, baking industry and meat processing industry up to a great extend but it rarely used for cooking. Ginger brine is most popular in Japan (Jiang et al., 2005).

Orissa, Kerala, Karnataka, Arunachal Pradesh, West Bengal, Sikkim and Madhya Pradesh are the major ginger producing states in India. Among which Kerala contribute 33 per cent to the total production by which it has prove to be the largest ginger producing state in India (Gupta, 2008). Cochin ginger and Calicut ginger are the popular Indian ginger varieties in the world market. India produces 6,83,000 tons of ginger per annum that is almost $1 / 3 \mathrm{rd}$ of world's total production (FAO). 30 per cent 
of total production of ginger in India is transferred to dry ginger, 50 per cent is taken as fresh or green ginger and the rest part is used as seed materials. Kerala is the largest producer of dry ginger in India, which has taken a major share in export.

\section{Nutrient composition}

Protein $(2.3 \%)$, Fat $(0.9 \%)$, carbohydrates $(12.3 \%)$, mineral $(1.2 \%)$, fiber $(2.4 \%)$ and moisture $(80.9 \%)$ are the main constituents of fresh ginger. Minerals like phosphorous, calcium, and iron present in ginger are iron, calcium and phosphorous. It also contains vitamins such as thiamine, riboflavin, niacin and vitamin $\mathrm{C}$. The composition varies with the type, variety, agronomic conditions, curing methods, drying and storage conditions (Table $1)$.

\section{Beneficial quality of ginger}

Ginger is a popular digestive aid and it is famous for its medicinal quality since its origin. Special active components have found in ginger that is responsible for easy digestion or best we can say it act as a trigger for digestion. It is also helps to get relieve from constipation or any unwanted disorder related to digestion. Due to its endless beneficial quality it has been used in Indian Ayurvedic as well as in Chinese medicine since ancient time. In Chinese medicine it was mainly used for easy transportation of body fluid as it accelerate circulation of blood in our whole body due to its amazing stimulatory effect on the heart muscle and by powerful capacity to dilute the blood (Zadeh and Kor, 2014).

Though its excessive doses may cause certain problem but from a study it was clear that it has no harmful effect on heart rate and blood pressure, also it does not involved with at least one study indicates that ginger has no effect on blood pressure, heart rate, or coagulation parameters and does not involved with anticoagulant drugs like warfarin (Weidner and Sigwart 2000). Later this result was again proven with double confidence saying ginger has no effect on clotting status or the pharmacokinetics or of warfarin in healthy subjects (Jiang, Williams et al., 2005).

Also, the medicinal, chemical, and pharmacological properties of ginger have been extensively reviewed by Surh et al., (1998), Ernst and Pittler (2000), Afzal et al., (2001), Bode and Dong (2004), Boone and Shields (2005), Borrelli et al., (2005), Chrubasik and Pittler (2005), Chrubasik et al., (2005), Grzanna et al., (2005), Thompson and Potter (2006), Eliopoulos (2007), White (2007), Ali et al., (2008), Nicoll and Henein (2009). Ginger is used worldwide as an ingredient in food and medicine. It has long been used to treat many gastrointestinal disorders and is often promoted as an effective antiemetic (Bhattarai et al., 2011) Gingerols, the pungent principles in the rhizome of ginger, are reported to have antiemetic, analgesic, antipyretic, anti-inflammatory, chemopreventive, and antioxidant properties (Shukla and Singh, 2007). They have also been suggested for treating various illnesses, including arterial sclerosis, migraine headaches, rheumatoid arthritis, high cholesterol, ulcers, and depression. (Yi, LT et al., 2010) 6-Gingerol, 6-shogaol, and other structurally related substances in ginger inhibit prostaglandin biosynthesis by suppressing 5lipoxygenase or prostaglandin synthetase (Kiuchi et al., 1992).

\section{Processing of ginger}

Two important factors must be considered at the time of choosing ginger rhizomes for further processing or for development of secondary products from ginger rhizome.

Maturity stage at the time of harvest Native properties of the type grown 


\section{The maturity stage at the time of harvest}

Age of the leaves and bulb size are two principal measurements used to determine harvesting time. Harvesting of ginger begin, as soon as the leaves become yellow and initiate to turn dry. This physical process generally best seen during 7 to 9 months after planting so this period is considered as typical harvesting time for ginger. Except this period ginger rhizomes may be harvested at the age of 5 month when they are immature. At this age they are may be of higher value and are considered to be fit for fresh consumption or for processing into preserved ginger as at this particular age they are less fibrous and tender with a mild flavor. This mild flavored rhizome gradually turns to less juicy, more fibrous and strong flavored rhizome at the age of 7 month. So it is not accepted for fresh consumption and they are then useful for making dried ginger. At this stage also the oil and oleoresin content is high. Late harvesting is generally not suitable as after complete yellowing of the leaves the ginger become more fibrous this is not desirable. Harvesting at this stage also limit storage life, and increase sprouting (Platto, 2002). So now it can be easily observed that the harvesting time can highly affect the quality of end use. Based on this the harvesting time of ginger for different end use has listed below (Source: FAO).

For fresh consumption: 5 months

For preserved ginger: 5-7 months

-For dried ginger: 8-9 months, when leaves start yellowing

For essential oil production: 8-9 months

\section{Native properties of the type grown}

Native properties of ginger such as taste, flavor, aroma and color will differ according to the different variety of ginger growing in different part of the world. This affects their suitability for processing. When preparing dried ginger it is most important to choose variety of rhizomes with a strong flavor and aroma. Also the size of rhizome plays an important role for ginger drying. In such situation medium sized rhizome are more appropriate to choose otherwise in contrast if we choose large rhizomes, it will not be suitable causing problems with drying due to its high moisture content. Condition medium sized rhizomes are the most suitable as the often have a high moisture content which causes problems with drying.

After selecting the ginger based on our end use we should proceed for processing which include some basic steps that are:

1. Cleaning 2. Sorting 3. Peeling 4. Drying 5. Grading and Packaging

\section{Cleaning}

Cleaning of harvested rhizomes should be necessary to remove debris, shoots and roots. Thorough cleaning of rhizome required immediately after harvest if ginger intended for export or for long-term storage. It is recommended to wash the rhizome in clean sanitized water with $150 \mathrm{ppm}$ hypochlorous acid either by scrubbing with hands or with a brush. Killing of rhizome was being followed by traditional method, in which rhizomes were dipped in boiling water for $10 \mathrm{~min}$. This method is useful in inactivation of enzymatic processes. Optimum sanitization by hypochlorous acid has found to be possible at a water $\mathrm{pH}$ of 6.5 . It has also recommended to apply fungicidal treatment which can be done by adding fungicides either in to the water at the time of washing or it may sprayed separately. Fungicides like benomyl (500 ppm active ingredient) or thiabendazole (1000 ppm) are recommended for this treatment. 
Another mode of washing is pressure washing which tends to reduce the microbial load more efficiently so it is preferred when available (NARI, 2004).

\section{Sorting}

Sorting is the process of grouping according to size, shape, weight, image and color. So in this process all the damaged and injured rhizomes got separated and the rhizomes are kept separated depending upon the similarity in size and shape. Clean, brown-yellow and bright colored ginger should prefer. Ruptured or blot skin with bacterial or fungal infected rhizome are not recommended (NARI, 2004).

\section{Peeling}

Peeling is the process of scrapping or slicing. Generally ginger peeling is done before drying for better result in moisture content reduction in short time. Reduction of drying time is essential to reduce mould growth and fermentation. Peeling of ginger is also a very important and sensible operation as there is a chance of decreasing the percentage of oil constituent which is present more in its peel. There is also a chance of oleoresin reduction which is found near to the skin of ginger. So maximum care should be taken at this process generally it is done with bamboo splits having pointed ends (Platto, 2002). Peeling of rhizome may be done or may not be done before drying; it typically depends on the area of growing and the variety of ginger. If ginger has not peeled and simply been washed and dried, then it is commercially known as "black" or "green" ginger, while the peeled product is known as "white" ginger.

\section{Slicing}

Slicing of ginger prior to drying is most important unit operation as large size of ginger rhizome will be difficult to process in to dried ginger due to high moisture content. But In such cases the volatile oil content is often below standard requirements. As the length of slice increased the essential oil content of sliced ginger also increased, and the maximum retention was found to retained in the whole dry rhizomes (Visvanathan and Zachariah, 2012).

\section{Drying}

Drying is an important unit operation, which is a part of ginger processing. Drying of ginger is equally essential for easy transportation and for reduction of waste. It is the process of removing the moisture up to a predetermined level by providing heat. Moisture movement and heat transfer, these two phenomena occur simultaneously in this process.

To give high yields with minimum cost to the village level processors the Ginger rhizome processing methods should be imaginative (Phoungchandang, 2010). Although various methods for drying of ginger are there but the very common and traditional method mostly used by the farmer in India is sun drying. Method of treating ginger after harvesting differs according to the country in which it is grown. According to the Indian Spice Board, general method for preparation of dry spices required the following sequence:

Soaking the rhizome with water and leaving it overnight

Peeling/scraping with pointed-end bamboo splinters

One week sun drying

Again soaking for 6 hours in water with $2 \%$ lime

Final drying up to $8-10 \%$ moisture (Should not exceed $12 \%$ ). 
During drying the normal weight loss is 60 $70 \%$.So drying of ginger is very much beneficial for transportation purpose. A minimum of 7 to 9 days is necessary to attain $7.8 \%$ to $8.8 \%$ moisture content in case of sundrying of peeled ginger where as a cross-flow drier took only 5 to 6 hours for sliced ginger. But for drying of whole ginger it will take minimum of 16 to 18 hours even if it has peeled. So it can be noted that in accordance with method of drying, peeling and proper size of rhizome also matter to reduce drying time.

It has found that more homogenous and cleaner product can be obtained from mechanical drying but the essential oil content and oleoresin content was found to be more in sun drying and solar tunnel drying as compare to mechanical drying. Air flow and temperature are the two important factors to be maintained properly in case of hot air drying. In this case of mechanical drying, the optimum drying temperature was considered as $60{ }^{\circ} \mathrm{C}$ because after this critical temperature the loss of essential oil and oleoresin is more than $12.2 \%$ and $5.3 \%$ respectively (Visvanathan and Zachariah, 2012).

\section{Grading and packaging}

Packaging of final processed product is done according to the homogeneity in size and quality. Dried ginger can be graded as peeled, unpeeled, scraped, rough, bleached, splits and slices based on the drying process. Wellventilated and strong containers are required which would be capable of being stacked without damaging the rhizomes at the time of packaging. Wooden crates are more preferred as compared to messy sacks and synthetic bags for the domestic market. Ginger rhizomes preferably packed in fiberboard carton for the export market. The bursting strength of the fiberboard should not be less than $275 \mathrm{lb}$ per square inch. A double-walled self-locking waxed carton or a corrugated carton with two-piece fully telescopic is preferred for this purpose. Overfilling of the carton must be avoided (Platto, 2011).

\section{Internationally accepted products of ginger}

\section{Dried ginger}

Dried ginger is the most important product in terms of trade after fresh ginger. Dried ginger is the raw material to make ginger powder and also for ginger oil and oleoresin extraction. It is obtained by drying of fully matured rhizomes, harvested at an age of 8 to 9 month. At this age the rhizomes have fully developed flavor, aroma and pungency. By converting in to dried form, ginger can be preserved for longer time. Dried ginger can be exported in two different forms, one is as whole peeled and other one is as sliced unpeeled. Chinese dried ginger has more export potential than Indian ginger because of its bright color and more fibrous characteristics (Plotto, 2011). The volatile oil and fiber content, the pungency level, aroma and flavor are need to be assessed for quality assurance of the dried form of ginger. Lower grades of coated whole, clean peeled, split and sliced types are used for blending in the preparation of powdered mixed spices. Varieties with high dry recovery percentage (>20\%), bold fingers and low fiber content $(<4 \%)$ are required for dry ginger production. Cochin and Calicut dry ginger exported from Kerala are two popular variety of India, produced from local cultivars, i.e. Kuruppampady, Cheranad, Erenad and Wayand local (Shanmugavelu et al., 2005). Dried ginger can be used directly as a spice after grinding and also used for the extraction of ginger oleoresin and ginger oil.

The yield of dry ginger is $16-25 \%$ of the green ginger. Dried ginger is available in different forms like the whole dried ginger, splits or slices and its quality greatly depends on the method of drying. 


\section{Ginger powder}

Ginger powder is rarely used in its pure form but it is an important ingredient of curry powder. It is also used in ginger wine, ginger beer and baked goods. Ginger powder can be found after grinding the dry ginger. So for ginger powder the main raw material is dry ginger. Ginger powder can be used as pharmaceuticals and used for the production of herbal medicines. It also used as food additive. Ginger powder also has a very good export market.

\section{Ginger paste}

Select good quality ginger, cut it into pieces and blend into a thick paste. Add vegetable oil (60 $\mathrm{ml}$ in $1 \mathrm{~kg}$ of paste) to the paste. Cook it for 5 minutes with continuous stirring. After it the ginger paste should packed in sterilized jar leaving a headspace of 5-10 $\mathrm{mm}$. Before sealing ensure to add one teaspoon of warm oil on the surface of paste. Then the packed ginger paste should be pasteurized at $85-90^{\circ} \mathrm{C}$ for $10 \mathrm{~min}$. Finally cool, level and store the ginger paste in a dry and cool place.

In India a 'ginger-garlic paste' is very popular which is generally made with $50 \%$ macerated and sliced ginger, $35 \%$ garlic and $15 \%$ salt in traditional procedure. Nowadays, it is available to the consumers in suitable packing with improved shelf-life of 12 month. A study was done and on effect of storage condition on rheological behavior of ginger paste and it was reported that the best storage condition of ginger paste achieve at $5 \pm 1{ }^{0} \mathrm{C}$ in polyethylene terephthalate or glass containers (Ahmed, 2003).

\section{Ginger syrup}

Ginger syrup can be made by using tender rhizomes. It can be used as an antiemetic agent and recommended for pregnant women
(Angela et al., 2002). Using ginger syrup we can make soda by adding lemon juice in to it. It is also widely used as a flavoring agent in many food and beverages

\section{Ginger oil}

Oil can be obtained from ginger mainly by two methods that are steam distillation and solvent extraction. However steam distillation method is mostly used for this process. Oil is contained in epidermal tissue of ginger and the odor in the oil is due to the presence of essential oils which posses aroma and flavor but not pungency. The oil was extensively produced by U.S.A and Europe but now it is commercially produced in all around the world by major spice producing countries notably in China, India, Australia, Jamaica and Indonesia (Lin et al., 2008). It has reported that the essential oil from fresh ginger is of better quality than that from dry ginger with respect to fragrant flavor. It has also stated Shogaol and gingerol are useful in foods, medicines, quasi-drugs, and cosmetics. (Wang et al., 2011) Gingerols can be separated with high purity from zinger by high-speed counter-current chromatography using stepwise elution. The oil can also be obtained from the ginger peel. The color content of the oil is generally yellowish and green in color with characteristic aroma and flavor. Ginger oil is used as a flavorant in food processing, pharmaceuticals and also in perfumery (Nybe et al., 2007). Zingiberene is found in varying concentration in the rhizome oils of plants growing in India (46.2\%), China $(38.12 \%)$, Nigeria $(29.0 \%)$, Australia (20$28 \%$ ), Mauritius (9.5\%), the Central African Republic (3.6\%) and Srilanka (1.3\%) (Fakim et al., 2002).

\section{Ginger oleoresin}

Oleoresin is the extract of ginger containing both volatile oil and pungent components. The 
volatile oil is responsible for the aroma and the pungency of ginger is come due to nonvolatile components. Oleoresin is an extracted product of ginger and it can be extracted by solvent extraction of powdered ginger. After distillation of the solvent we can get the final product. The solvents used for this purpose should be efficient and non-reactive. Normally acetone and alcohol are more preferred for this purpose.

Ginger oleoresin is a important product as per the export of ginger. It has a grade demand both in India and in outside country. It is more popularized product in food industries as it can be used in sauces, soft drinks, beverages, baked goods, sweets and many more. It has also been used as a health benefit product due to its antioxidative and anti-inflammatory property. It can be used as a remedy for nausea and for all digestive problems. Ginger oleoresin is a viscous liquid with dark brown color. Value and quality of oleoresin can be evaluated by its essential oil content.
Normally 15 to $35 \%$ of volatile oil is present in ginger oleoresin. Commercially it is known as gingerin. The average yield of oleoresin from ginger is $6.5 \%$ which may be ranging from 3.9 to $9.3 \%$.

\section{Preserved ginger}

Ginger candy or crystallized ginger, ginger in brine or syrup are the main types of preserved ginger. For this purpose less fibrous with mild pungency tendered ginger is best suited. Preserved ginger is very popular in Australia and Japan. It is also a favorite form of ginger in India as well like in northern part of country 'murabba' is a choice of many.

But here in India the quality of ginger used for preparation of preserved ginger is not satisfactory even if it is the largest country as per the production is concern. Dipping in brine or syrup with dissolving sugar is the best method has been adopted in India for making preserved ginger (Brown, 1969).

Fig.1 Statistics of export of ginger from India

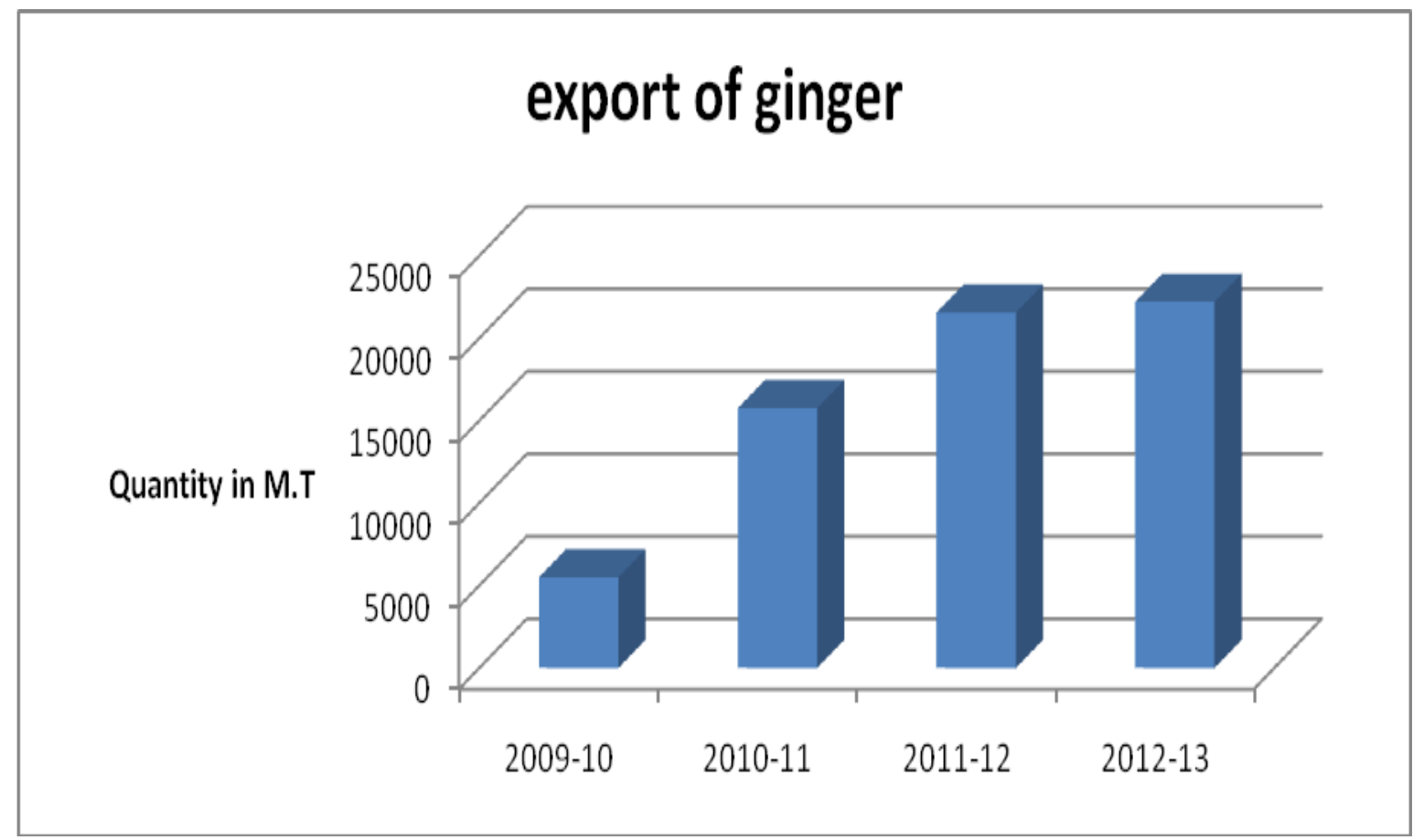

[Source: DGCI\&S., Kolkata/Exporters] 
Table.1 Nutritional data for $100 \mathrm{~g}$ dry ginger

\begin{tabular}{|l|l|}
\hline Water & $\mathbf{9 . 4} \mathbf{g}$ \\
\hline Protein & $9.1 \mathrm{~g}$ \\
\hline Food Energy & $347 \mathrm{kcal}$ \\
\hline Fat & $6.0 \mathrm{~g}$ \\
\hline Total Carbohydrate & $70.8 \mathrm{~g}$ \\
\hline Fiber & $5.9 \mathrm{~g}$ \\
\hline Ash & $4.8 \mathrm{~g}$ \\
\hline
\end{tabular}

Source: Book on "Herbs and Spices" Second Edition Volume 1.

\section{Government schemes}

\begin{tabular}{|c|c|}
\hline COMPONENTS & OBJECTIVES AND SCALE OF ASSISTANCE \\
\hline Organic ginger & $\begin{array}{l}\text { To promote organic production of ginger in north east states, } \\
\text { Rs. } 18750 / \text { - per ha is providing as subsidy towards } 50 \% \text { of the cost of } \\
\text { the planting materials. }\end{array}$ \\
\hline $\begin{array}{l}\text { Spice slicing machine for } \\
\text { ginger }\end{array}$ & $\begin{array}{l}\text { With the aim to improve the quality of dried ginger government is } \\
\text { motivating the ginger grower to adopt slicing of ginger before drying } \\
\text { by providing } 50 \% \text { subsidy on ginger slicing machine which subject to a } \\
\text { maximum cost of Rs. } 7000 / \text { - to the growers. }\end{array}$ \\
\hline $\begin{array}{l}\text { Dry/fresh } \\
\text { ginger peeling } \\
\text { \& storage unit }\end{array}$ & $\begin{array}{l}\text { Government is also promoting setting up of primary processing } \\
\text { facilities for ginger in the growing areas keeping the objective to } \\
\text { improve the quality of ginger Board is providing } 50 \% \text { of the cost for } \\
\text { setting up of equipments required for setting up of primary processing } \\
\text { facilities and accessories for storage subject to a maximum of Rs. } 5 \\
\text { lakh as subsidy. }\end{array}$ \\
\hline $\begin{array}{l}\text { Dry/fresh } \\
\text { ginger peeling } \\
\text { \& storage unit }\end{array}$ & $\begin{array}{l}\text { The objective of the scheme is to improve the quality of ginger } \\
\text { By promoting setting up of primary processing facilities for ginger in } \\
\text { the growing areas. Board will provide } 50 \% \text { of the cost for setting up of } \\
\text { equipments required for setting up of primary processing facilities and } \\
\text { accessories for storage subject to a maximum of Rs. } 5 \text { lakh as subsidy. } \\
\text { No assistance will be given for construction of building purpose }\end{array}$ \\
\hline $\begin{array}{l}\text { Spice Washing } \\
\text { Equipment }\end{array}$ & $\begin{array}{l}\text { The objective of the scheme is to motivate the growers to adopt } \\
\text { washing of spices after harvest by using washing equipments to } \\
\text { improve quality of the produce for export. } 50 \% \text { cost of the equipment or } \\
\text { Rs.1.10 lakh per unit is offered as subsidy }\end{array}$ \\
\hline
\end{tabular}

(Source: Spice Board of India)

\section{Flavoring applications}

\section{Culinary}

Ginger has been used as a flavoring agent in cooking since ancient time. Probably the first name comes into mind by saying simply ginger is 'spice' as it is widely being used in all type of non-vegetable and vegetable food preparation.

The kind of freshness that ginger can add to food the other spices could never match. A tenderizing effect can be observed, while 
cooking meat with pieces of fresh ginger, which is very unique characteristic of ginger (Lawrence, 1984).

\section{Ginger bread}

For the preparation of ginger bread the main ingredients we need are finely grated fresh ginger, ginger juice and dough of ginger powder. Addition of other spices like garlic, cinnamon, and clove may be recommended depending on the taste (Pruthi, 1993).

\section{Ginger biscuits, cookies, and cakes}

Ginger is hard to eat as such so products like ginger biscuits, cookies, cakes make it delicious and tasty. Ginger as a traditional food is unique in its warm spicy flavor so its small amount of addition can also bring the actual feel of its aroma and flavor.

For the purpose of making biscuits, cakes and cookies a typical dose of one teaspoon of ginger powder for four cups of flour is sufficient. Sometimes cinnamon and nutmeg are also added in small quantity depending upon the taste and flavor.

Among ginger manufacturers in India, Asian food and health care and Bakewell biscuit pvt. ltd are well known company producing ginger biscuits. Bakewell biscuit pvt. Ltd has originated from Gujarat which was established in 1994.

\section{Ginger drinks}

Ginger drinks provide a cool, refreshing beverage as well as assistance health benefits. Ginger ale and the ginger beer are two most popular ginger drinks which are carbonated ginger, flavored with soft drinks. Ginger ale and ginger beer are very similar but sometimes the spicier ginger ales are termed as "ginger beer".
Many researchers have been done on various types of ginger drink. A ginger based appetizer in ready to drink form was developed and found to be beneficial with a shelf life of 6 month (Wadikar et al., 2011). This product is more useful in high altitude as there loss of appetite and reduction in weight is a main problem. The ginger based appetizer was made by taking the main ingredients; fresh ginger, lemon and sugar following the processing step as given in flow diagram. A earlier study was also done to develop ginger based ready to eat appetizer in the form of chewy much using fresh and powdered ginger (Wadikar et al., 2011). But appetizer in ready to drink form was found to be more effective than ready to eat form as in high altitude the environment effect makes consumer to prefer liquid food. (Singh et al., 1997).

Some of the ginger based blends or beverages such as ginger-honey beverage (Yanzhong, 2003), ginger-lemon blend with grape juice concentrate and Echinacea (rw Knudsen family 2011), plum liqueur with blend of lemon and ginger (Wadikar and Premavalli, 2011) and various recipes of ginger-lemon blend and also tea blends have been reported.

\section{Ginger Wine}

Ginger wine is a very popular warming kind of beverage so it is generally more likely and accepted in winter season. For preparation of ginger wine brewing is done by fermenting grapes with addition of ginger, sugar and yeast. For preparing one liter of wine generally 50 gram of ginger is required. It serves best in taste after 3 to 4 month of storage. It may be taken as such or may be after blending with alcoholic drink.

\section{Ginger tea}

Ginger tea is very popular and medicinal drink as it can cure common cold, flu, throat 
pain beside this it has also many health benefits thus taken as a refreshing drink. This ginger tea is basically prepared by cooking cut fresh ginger with water for a minimum of 5 to $10 \mathrm{~min}$ for its flavoring application. Then ginger tea can be served by adding sugar or honey in to it as per the taste is required. This is preferred both in winter as well as in summer season. In place of fresh ginger, powdered ginger can also be used as per the availability. Ginger tea is best serve as a digestive aid after every meal.

\section{Ginger syrup}

Ginger syrup can make perfectly spiced sweet ginger drinks. To make ginger syrup, boil 50 $\mathrm{g}$ of finely chopped ginger in sugar syrup containing one cup of sugar in two cups of water. Simmer and cook for 1 hour. Strain the liquid and add vanilla or lemon essence to taste. Cover and refrigerate. This syrup will keep for several days. The concentrated syrup may be extended with carbonated or plain water. The syrup could also be drizzled over ice cream. The syrup from candied/crystallized ginger processing can also be used in the same way.

\section{Ginger coffee}

Ginger coffee is a blend of roasted coffee powder and ginger powder. A hot beverage is prepared by boiling the powder in water. Milk and sugar are optional. Ginger coffee is a cordial beneficial in the cold weather and is a remedy for colds, cough, and flu.

\section{Ginger candy}

For preparation of ginger candy the basic raw material first we have to select is young ginger having low fiber content. Then it should be peeled properly after washing The washed ginger should cut it to pieces of 1-2 $\mathrm{cm}$ thickness and boil the ginger pieces so that it become soft. After boiling for $1 \mathrm{hr}$ the ginger pieces should be kept in shed and allow it to dry. After it the ginger pieces should mix with sugar (1 kg ginger pieces: $1 \mathrm{~kg}$ sugar) and kept it for $24 \mathrm{hr}$. Then on the next day remove the ginger pieces and add $2 \mathrm{gm}$ citric acid to the sugar syrup boil it up to $60^{\circ}$ brix. Then cool the syrup and add ginger pieces into it and kept for $24 \mathrm{hr}$. repeat the same procedure on the third and fourth day also with $65^{\circ}$ and $75^{\circ}$ brix sugar syrup. After this allow the syrup to cool and add the ginger pieces and keep it for 4 days. Then remove the well soaked ginger pieces and oven dry it at $60^{\circ} \mathrm{c}$ for $6-8 \mathrm{hr}$. these dried pieces then coated with powdered sugar or glucose powder. The final ginger candy than can be stored in cool and dry

\section{Optimum processing conditions}

To avoid anti browning effect on ginger candy care should be given on three things that are thickness of ginger slices, processing treatment and the condition of drying. Instate of sulphite a combination of all three or any two among, phytic acid, citric acid, and disodium ETDA was found to be giving better result. So Ginger slices (1-2mm thickness) should blanch for $10 \mathrm{~min}$ in $0.1 \%$ citric acid and $0.02 \%$ disodium ETDA solution. Then soaked it in a solution of $0.1 \% \mathrm{cacl}_{2}$ for $2 \mathrm{hr}$ and then washed off the anti-browning solution, alternatively heated and soaked in sugar solution and finally dried at $40^{\circ} \mathrm{c}$. This method can help to retain the original color of ginger candy rather than browning (Kaiju et al., 2005).

\section{Export potential for ginger}

2000 years ago ginger was exported from India to the Roman Empire and Arab merchants controlled the ginger trade. During the 13th and 14th centuries ginger became one of the most commonly traded spices 
(Abubacker, 2011). And its value is gradually increasing with time as per 'UN COM TRADE' statistics the value of ginger has increased 11\% from the year 2006 to 2011. In 2012-13 the export value of world exports has risen by spices having export code of ' 0910 ' and ginger was one important spice among them whose export value stood at 316 million us dollar(FAO STAT). Supply of ginger in the world market is lead by Asian countries. The major importers are Japan and USA. Mainly whole and dry ginger is exported from India. 'Cochin Ginger and 'Calicut Ginger' are the two popular dry gingers in the global market. Cochin Ginger is accepted as one of the best ginger in the world. In the recent past, India's competitors in the world market are China, Nigeria and Thailand. And China has the major export share.

Whereas India contribute only $9.3 \%$ to the world's total export of ginger (UN COM TRADE statistics, 2012). From which India has $50 \%$ share in the trade of oil and oleoresin. Top five importers of ginger from India are USA, UK, UAE, Saudi Arabia, and Nepal (Agri export advantage, 2014

\section{Guideline for export}

For export the minimum rhizome size is $250 \mathrm{~g}$ whereas there is no maximum size limit. The main stem of $3 \mathrm{~cm}(1.25$ in) thick and $12 \mathrm{~cm}$ (5 in) long is preferred. A large rhizome with limited branching is requiring as per the market demand. Rhizomes having more than 4 side branches should not preferred for export. Export quality ginger should be smooth and firm, having tight and light brown skin with uniform shape and size, be free from insect damage and decay.

\section{Export strength of India}

India is a leading ginger producer in the world. More than $50 \%$ of total ginger production takes place in North East, Uttarakhand and Sikkim states. Most of ginger in North Eastern states is produced under organic conditions. India has identified / developed a number of superior and high yielding cultivars. There is strong research support in this crop, as Indian Institute of Spices Research, Kozhikode, Kerala and State Agricultural Universities are operating in ginger growing areas. APEDA has already sanctioned Agri Export Zones for fresh ginger in Assam, Orissa and Sikkim, for enhancing exports. Indian Spices Board established under the Ministry of Commerce, provides further support for expansion of area under spices and enhancing exports (Fig. 1).

\section{Measures for enhancing competitiveness for export}

India main competition in ginger is with China, Indonesia and Thailand. China is able to provide much bigger finger size at cheaper prices in International market. Therefore, India needs to percolate its superior and high yielding cultivars like IISR Varada etc. through micro tubers with the help of tissue culture in states like Assam, Mizoram, Meghalaya, Sikkim and Orissa, in order to bring sizeable area under superior cultivars.

\section{Government schemes}

India government is showing a great effort by proving many schemes and facilities in order to promote the production as well as postharvest practices of ginger. The only step the farmer has to take is to submit an application in a prescribed manner to the nearest Spice Board with all the documents. Some of the important schemes and facilities are provided in the following table.

From the above study it was observed that the production as well as productivity of ginger has been increasing since past few years. The 
main reason of this growth is increasing demand of ginger in various forms. Moreover a greater share of its production also contributes to export of various product of ginger. India has reached to the top position in ginger production but still we have to go longer though we could not able to beat China in export of ginger yet. China contribute almost 50 percent to the total export of ginger in world while India contribute only 9.5 percent. (FAO)

To improve the status of ginger production and processing we have to be more careful about product diversification, expansion of market as well as branding the products. A bit attention towards basic processing action like cleaning, sorting, grading and packaging can create extra benefit to the producers.

\section{References}

Abubackar, A. T. N. 2011. Ginger: A rhizome with high export value.

Afzal, M. et al., 2001. Ginger: An ethno medical, chemical and pharmacological review. Vol 18(3-4), 159-90.

Badreldin, H. A. et al., 2008. Some phytochemical, pharmacological and toxicological properties of ginger (Zingiber officinale Roscoe), Food and Chemical Toxicology. Vol 46(2), 409-420.

Bhattarai, S., Tran, V.H., Duke, C.C. 2001. The stability of gingerol and shogaol in aqueous solutions, Journal of Pharmaceutical Sciences. Vol 90(10), 1658-1664.

Bode, A. M., Dong, Z. 2004. Ginger-Herbal and Traditional Medicine: Molecular Aspects of Health.

Bode, A. M., Dong, Z. 2011. The Amazing and Mighty Ginger, Herbal Medicine - NCBI Bookshelf, second edition.

Boone, S. A., Shields, K. M. 2005. Treating pregnancy-related nausea and vomiting with ginger. Vol 39(10).

Borrelli, F. et al., 2005. Effectiveness and safety of ginger in the treatment of pregnancyinduced nausea and vomiting. Vol 105(4), 849-56.
Brown, B. I. 1969. Processing and preserving ginger by syruping under atmospheric conditions, Journal of food Technology. 9396.

Chrubasik, S., Pittler, M. H. 2005. Addendum to a recent systematic review on ginger, Forsch Komplementarmed Klass Naturheilkd. Vol 12(3), 168-9.

Chrubasik, S., Pittler, M. H., Roufogalis, B. D. 2005. Zingiberis rhizoma: A comprehensive review on the ginger effect and efficacy profiles, Phytomedicine. Vol 12(9), 684701.

Datta, S.K., Singh, G. 2003. Chakrabarti, M. Ginger and Its Products: Management of Marketing and Exports with Special Reference to the Eastern Himalayan Region.

Datta, S.K., Singh, G., Chakrabarti, M. 2003. Ginger and Its Products: Management of Marketing and Exports with Special Reference to the Eastern Himalayan Region. National Consultative Meeting for Improvement in Productivity and Utilization of Ginger, May 12-13.

Eliopoulos C. 2007. Ginger: More than a great spice. Vol 15(1), 46-7.

Ernst, E., Pittler, M. H. 2000. Efficacy of ginger for nausea and vomiting: A systematic review of randomized clinical trials. Vol 84(3), 367-71.

George, L. 1996. The Ginger economy of Kerala.

Govindarajanvs; 1982. Ginger - chemistry, technology and quality evaluation: part-2. Food Sci. Nutrition. Vol (17), 189-258.

Grzanna, R., Lindmark, L., Frondoza, C. G. 2005. Ginger-an herbal medicinal product with broad anti-inflammatory actions. Vol 8(2), 125-32.

Gupta, R.K. 2008. Ginger - A Wonderful Spice: An Overview. International Journal of Plant Research. Vol 21(1), 1-10.

Jayashree, E., Visvanathan, R., Zachariah T. 2012. Quality of dry ginger (Zingiber officinale) by different drying methods, Journal of Food Science and Technology.

Jiang, X. et al., 2005. Effect of ginkgo and ginger on the pharmacokinetics and pharmacodynamics of warfarin in healthy subjects. Vol 59(4), 425-32. 
Jiang, X. et al., 2005. Effect of ginkgo and ginger on the pharmacokinetics and pharmacodynamics of warfarin in healthy subjects. Vol 59(4), 425-32.

Kaiju, M. et al., 2005 Xingping, W., Chao, C. Ginger candy processing technology and anti-browning without sulphite.

Kiuchi, F. 1992. Inhibition of prostaglandin and leukotriene biosynthesis by gingerols and diaryl heptanoids, Chemical and Pharmaceutical Bulletin. Vol 40(2), 387391.

Kubra, R., Rao, J.M. 2012. An Impression on Current Developments in the Technology, Chemistry, and Biological Activities of Ginger (Zingiber officinale Roscoe), Journal of Food Science and Nutrition. Vol 52(8), 651-688.

Kulkarni, R. et al., 2012. Deshpande. Ginger supplementary therapy for iron absorption in iron deficiency anemia, Indian Journal of Traditional Knowledge Vol 11(1), 78-80.

Malhotra, S., Singh, A.P. 2003. Medicinal properties of ginger. Department of Pharmacology. Vol 2 (6).

Nguanpuag, K. et al., 2011. Ginger (Zingiber officinale) Oil as an Antimicrobial Agent for Minimally Processed Produce: A Case Study in Shredded Green Papaya, International Journal of Agriculture \& Biology.

Plotto, A. 2011. Post-production management for improved market access for herbs and spices - ginger.

Plotto, A. 2011. Post-production management for improved market access for herbs and spices - ginger. Post-harvest Compendium. FAO, Rome.

Plotto, A. 2011. Post-production management for improved market access for herbs and spices - ginger, Post-harvest Compendium. FAO, Rome.
Pruthi JS (1993) Major Spices of India - Crop Management Post-harvest Technology. ICAR, New Delhi.

Shanmugavelu, K. G., Kumar, N., Peter, K. V. 2005. Production Technology of Spices and Plantation Crops. Agrobios, India, 165-79.

Shukla, Y., Singh, M. 2007. Cancer preventive properties of ginger: A brief review, Food ChemToxicol. Vol 45(5), 683-90.

Sills, V.E. 1959. Ginger products. Fiji Agricultural Journal. Vol 29, 13-16.

Singh, S.B. et al., 1997. High altitude effects on human taste intensity and hedonics. Vol 68, 1123-1128.

Surh, Y. J., Lee, E., Lee, J. M. 1998. Chemoprotective properties of somepungent ingredients present in red pepper and ginger. Vol 402(1-2), 259-67.

Suthar, A.C. et al., A review on ginger (Zingiber officinale):

Thompson, H. J., Potter, P. J. 2006. Review: Ginger prevents 24 hour postoperative nausea and vomiting. Vol 9(3), 80 .

Wadikar, D. D. et al., 2010. Development of ginger based ready to eat appetizers by response surface methodology. Vol 55 (1), 76-83.

Wadikar, D. D., Premavalli, K. S. 2011. Optimization of ginger-based ready-todrink appetizer by response surface methodology and its shelf stability. Vol 55, 76-83.

Yanzhong, H. 2003. Preparation of ginger honey beverage. European Patent CN1421161.

Yi, L.T. et al., 2010. Antidepressant-like effects of monarch drug compatibility in Banxia houpu decoction. Chinese Journal of Natural Medicines. Vol 8(5), 362-369.

Zadeh, J. B., Kor, N. M. 2014. Physiological and pharmaceutical effects of Ginger (Zingiber officinale Roscoe) as a valuable medicinal plant. Vol 4(1), 87-90.

\section{How to cite this article:}

Bijaya B. Bag. 2018. Ginger Processing in India (Zingiber officinale): A Review. Int.J.Curr.Microbiol.App.Sci. 7(04): 1639-1651. doi: https://doi.org/10.20546/ijcmas.2018.704.185 